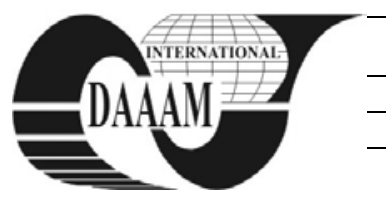

\title{
JUSTIFICATION OF AMTS USING THE APPROACH OF REAL OPTIONS
}

\author{
PALKA, P[remysl] \& PASTUSZKOVA, E[liska]
}

\begin{abstract}
The paper deals with the topic of real options in relation to the application of this approach to investment decisions in the field of advanced manufacturing technologies. The main result of the paper is a summary procedure and methodology for evaluating the effectiveness of AMT investments using real options as a suitable tool for the quantification of flexibility value of these investments.

Key words: advanced manufacturing technologies, real options, capital budgeting, volatility determination, simulation

\section{INTRODUCTION}

Increasing dynamism, development of information systems and technologies, pressure on the speed of innovation, shift towards less tangibles or soft issues affecting competitiveness, all that while sustain flexibility. Under those conditions and challenges many manufacturing companies are working. Part of the solution how to remain competitive lies in investment in AMT. The aim of this paper which is based on the research in progress is to present concrete mechanism of correct AMT justification as a key process for in companies' future competitiveness. The following parts discus used concepts and present created methodology.
\end{abstract}

\section{CONCEPT OF AMT}

Manufacturing technology moderates the relationship between strategy and organizational performance. Thus manufacturing technologies need to be consistent with business strategy. Successful deployment of technology helps to build a competitive advantage thereby enhancing organizational performance. Effects at level of positive and negative impacts on financial performance of firms can be explored and measured as well (Pathirawasam, 2010). Advanced Manufacturing Technology (AMT) refers to the family of technologies that include computer-assisted design and engineering systems, materials resource planning systems, automated materials handling systems, robotics, computer numerically controlled machines and other manufacturing advanced systems. However the relatively high cost of AMT and the moderate-to-high risk involved in adopting these technologies underscore the need for investment justification (Small \& Chen, 1995). Therefore management is very often placed in a dilemma in that on the one hand they wish to invest in new technology, such AMT, but on the other hand they find it difficult to justify the capital expenditure using the traditional appraisal techniques. The conventional financial evaluation methods are well-established, well documented, while the methodologies for the evaluation of the strategic, intangible benefits are less formalized and often less understood (Lefley, 1996). Combination of modern management concepts can be used (Januska, 2009) and synergic effects that can be gained by using these concepts together may appear (Knapkova, 2010). To justify advanced manufacturing systems, Raafat (2002) based on previous work, provides a comprehensive bibliography and reviewed literature concerning investment appraisal techniques for AMT and provides an excellent framework. As a most convenient management tool for justifying AMT seems to be combination of net present value and real options (Mun, 2006; Copeland \& Antikarov, 2001; Brennan \& Triegorgis, 2000).

\section{CONCEPT OF REAL OPTIONS}

Real options could be used as a beneficial tool for valuing managerial flexibility to adapt decisions in response to unexpected market developments and changes. Companies create shareholder value by identifying, managing and exercising real options associated with their investment portfolio. The real options method applies financial options theory to quantify the value of company's management flexibility in a world of uncertainty and frequent changes. If used as a conceptual tool, it allows management to characterize and communicate the strategic value of an investment project and accept them. Traditional methods (e.g. Net Present Value) fail to accurately capture the economic value of investments in an environment of widespread uncertainty and rapid change. The real options method represents the new technique for the valuation and management of strategic investments. The real option method enables corporate decision-makers to leverage uncertainty and limit downside risk (Mun, 2006). Just as an option gives its owner the right - but not the obligation - to take a particular course of action at some time in the future, flexibility embedded in capital investment projects and company strategies allows managers to take a staged approach to corporate strategy and react to changes in the business environment, so they can limit downside losses while fully capitalizing on upside potential opportunities.

\section{METHODOLOGY FOR EFFECTIVENESS VALUATION OF AMT INVESTMENTS}

In the following part authors would like to present the key parts of created methodology for AMT justification as a main result. The methodology was created and based on the method of structured discussion with the managers of nine Czech companies and the questionnaire received from 383 Czech companies. Only $12(=3,1 \%)$ companies out of $383(100 \%)$ are using real options while $270(=70,5 \%)$ of them prefer payback period. Net present value (NPV) concept is used by 107 (=27,9\%) companies. Following subchapters describe closely contents of each step that are presented on figure 1 .

\subsection{Cash-flow projection}

Firstly is generally needed to create a plan of future cashflows (CFs) for chosen AMT investment. Time span for that section depends on the lifetime of investment.

\subsection{Net present value calculation}

Based on the details from the CFs plan is calculated NPV. Regarding generally accepted rules for rejecting the projects with negative NPV and contrariwise. 


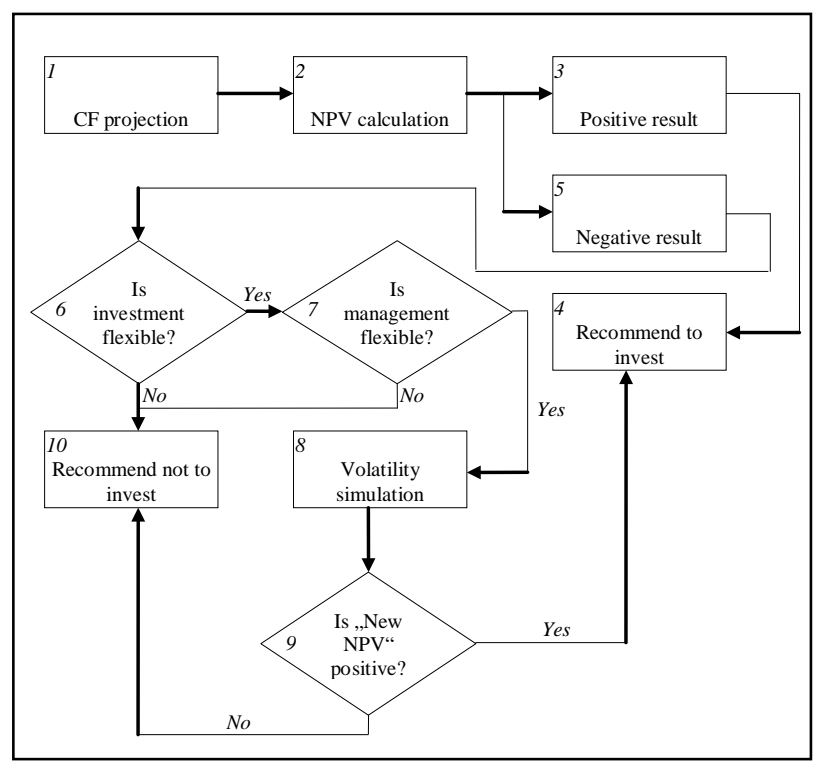

Fig. 1. Key steps in process of technology valuation

\subsection{Investment flexibility}

One of the key attribute of AMTs is their flexibility and adaptability to the customer's requirements (Chodur et al., 2010). But flexibility in this step was not evaluated yet. Speaking about flexibility value always means speaking about positive values. So we are challenging that task only if NPV from the $2^{\text {nd }}$ step is negative.

\subsection{Management flexibility}

If the investment is flexible it doesn't create real value by itself. We need to have competent management that will be constantly able to search for possibilities on market and at the right time will use the flexibility of implemented AMT and transform it to the real value? To test the level of management flexibility we arrange an indicator called "VRO" that is based on 24 parameters and can help to answer previous question.

\subsection{Volatility determination and an option value calculation}

If both, management and investment, are flexible than we need to calculate its value. For calculation of the value of flexibility is beneficial and recommended to use the tool of real options (Mun, 2006; Copeland et al., 2001). Most of the practical problems we had to face during our project came from the volatility parameter assessment. Out of five generally known parameters influence volatility the final option value the most. To set volatility correctly you can use several models (Brennan \& Trigeorgis, 2000; Copeland et al., 2001). Contrary to Mun (2006) we suggest to build the calculation on simulated NPVs instead of simulated CFs. We suggest going back to the $1^{\text {st }}$ step - CF projection. Each parameter of CF calculation must not be taken as a one concrete number, but interval going from minimum to maximum possible values. Between these borders we recommend to run simulation and for each set of number calculate NPV. Volatility is than the standard deviation of received NPVs.

\subsection{Final interpretation}

Adding value of an option to the NPV (from the 2nd step) presents „New NPV“, which is correct. For interpretation apply the same rules as presented in the step 3 and 5 .

\section{FURTHER RESEARCH}

The model for volatility calculation using Monte Carlo simulation principals is prepared but doesn't allow dealing with the correlation of certain parameters. That is currently the main focus of authors.

\section{CONCLUSION}

We discussed the procedure how the companies should correctly evaluate and justify AMT investments using real option concept. We firstly introduced the topic of AMT investments and real options. Based on the attribute of flexibility of implemented AMT we recommended concept of real options in process of justifying. Finally we presented the basics steps of suggested methodology for correct AMT evaluation.

\section{ACKNOWLEDGEMENT}

This paper was supported by the Czech Science Foundation (GACR). Project identification no. GA402/09/1739: Creating a Model for the Performance Measurement and Management of Enterprises (2009-2011, GA0/GA)..

\section{REFERENCES}

Brennan, M. J. \& Trigeorgis, L. (2000). Project Flexibility, Agency, and competition. New developments in the theory and Application of Real Options, Oxford University Press, 978-1-58799-186-8, New York

Copeland, T.; Antikarov, V. (2001). Real Options, Revised Edition: A practitioner's guide, Cengage Learning, 978-158799-186-8, New York

Chan et al. (2001). Investment appraisal techniques for advanced manufacturing technology (AMT): a literature reviw. Integrated Manufacturing Systems, Vol. 12, No. 1, pp. 35-47

Chodur, M.; Palka, P. \& Palikova, K. (2010). Value Chain Creation Process from the Perspective of Virtual Enterprise, Annals of DAAAM for 2010 \& Proceedings of the 21st International DAAAM Symposium, 20-23rd October 2010, Zadar, Croatia, ISSN 1726-9679, ISBN 978-3-901509-735, Katalinic, B. (Ed.), pp. 0707-0708, Published by DAAAM International Vienna, Vienna

Januska, M.; Palka, P.; Sulova, D. \& Chodur, M. (2009). Value Chain of Virtual Enterprise - Possible Modern Management Concepts and Value Drivers Identification, Annals of DAAAM for 2009 \& Proceedings of the 20th International DAAAM Symposium, 25-28th November 2009, Vienna, Austria, ISSN 1726-9679, ISBN 978-3-901509-70-4, Katalinic, B. (Ed.), pp. 0469-0470, Published by DAAAM International Vienna, Vienna

Knapkova, A.; Pavelkova, D. \& Jircikova, E. (2010). Possibilities for the utilization of concepts BSC and EVA for measuring and managing performance with the support of benchmarking, Knowledge Management and Innovation: A Business Competitive Edge Perspective, 6-7th November 2010, Cairo, Egypt, ISBN 978-0-9821489-4-5, Soliman, KS (Ed.), pp. 731-743, Published by Int. Business Information Management Assoc-IBIMA, Norristown

Lefley, F. \& Ryan, B. (2005). The Financial Appraisal Profile Model, Palgrave Macmillan, 1-4039-4752-X, New York

Mun, J. (2006). Real Options Analysis. Tools and Techniques for Valuing Strategic Investments and Decisions, John Willey \& Sons, 978-0-471-74748-2, New Jersey

Pathirawasam, C.; Knapkova, A. \& Kramna, E. (2010). Financial Performance of Selected Firms in the Czech Republic, Knowledge Management and Innovation: A Business Competitive Edge Perspective, 6-7th November 2010, Cairo, Egypt, ISBN 978-0-9821489-4-5, Soliman, KS (Ed.), pp. 781-789, Published by Int. Business Information Management Assoc-IBIMA, Norristown

Raafat, F. (2002). A comprehensive bibliography on justification of advanced manufacturing systems. International Journal of Production Economics, Vol. 79, No. 3, October 2002, pp. 197-208 